\title{
Erdogans nabokrige er kurdernes held
}

\section{Pola Rojan Bagger}

Demonstrationerne omkring Gezi Parken er uventede chikaner på regeringens vej mod et politisk forlig med PKK. Men forhandlingerne med den kurdiske oprørsbevægelse drejer sig om udviklingen i Syrien, og her er motivationen uændret for regeringen: Det haster!

Billedet er blevet et ikon; et symbol på det eneste, den tyrkiske premierminister Erdogan frygter - bortset fra Gud. Den unge mand er højst i midten tyverne. Han er drivvåd fra vandkanonens stråle og har et klæde for næse og mund som et fattigt værn mod den kvælende tåregas. I den ene hånd har han et gult flag med initialerne BDP for landets kurdiske oppositionsparti Freds- og Demokratipartiet. Med et fast greb om håndledet nærmest trækker han en jævnaldrende kvinde efter sig gennem gasskyerne. Hun er ligeledes maskeret og gennemblødt. I sin frie hånd bærer hun en rød-hvid tyrkisk fane med en stor kontrafej af general Mustafa Kemal tværs hen over halvmåne og stjerne.

\section{Et polariseret land}

Pressefotografiet fra starten af juni gik landet over og trak store overskrifter med sig. Historien om Republikken Tyrkiet er nemlig ikke mindst historien om en 90 år lang blodig kamp mellem Mustafa Kemals nationalister og landets løsrivelsesivrige kurdere. Ud over at symbolisere det tværpolitiske aspekt af massedemonstrationerne omkring Gezi Parken og Taksim Pladsen i Istanbul, gav fotografiet og dets symbolik næring til et håb i store dele af befolkningen.

Håbet om, at Tyrkiets meget fragmenterede opposition en dag kan finde sammen og for alvor udfordre det islamiskkonservative regerings- 
parti, Retfærdigheds- og Udviklingspartiet, AKP.

Før urolighederne var dette snarere en illusion, der afslørede desperation og ønsketænkning i skyggen af en historisk stærk regering. Tyrkiet er et anspændt og stærkt polariseret land med meget lidt empati og lydhørhed på tværs af politiske og etniske skel i befolkningen.

De seneste mange årtier har tyrkisk politik befundet sig i en permanent tilstand af krise. Som en hærdet knude af mistillid og fjendskab, der også afspejler sig i parlamentets daglige arbejde.

Ligesom politiske forlig er en sjældenhed, udløser det med garanti en gul bjælke i tyrkiske elektroniske medier, hvis landets premierminister og oppositionsleder skulle mødes til en samtale. Det er således nok til øjeblikkeligt at blive mediernes tophistorie, hvis parlamentets to mest indflydelsesrige politikere skulle udveksle to ord.

Det omtalte fotografi såvel som myndighedernes overreaktion på protesterne omkring Gezi Parken forstås bedst i denne bredere sammenhæng.

Her spiller regeringschefens ledelsesstil også en vigtig rolle. Det eneste, AKP og premierminister Recep Tayyip Erdogan frygter, er partiets egne vælgere. Den bedste måde at sikre deres ubetingede støtte på er ved at antagonisere og dæmonisere oppositionen og den øvrige vælgerbefolkning for derved at fremmed- gøre AKP-vælgerne fra 'de andre' mest muligt.

Det gør Erdogan blandt andet ved at betegne demonstranterne som 'plyndrere', 'terrorister' og 'alkoholikere', og ved at insinuere, at de skulle være gudløse ateister. På denne måde får han også kommunikeret, at AKP-vælgernes interesser grundlæggende er i strid med den øvrige befolknings interesser.

Den bløde 'del og hersk'-formel kombineret med værdipopulistiske kampagner målrettet et udpræget vestenkritisk, sunni-konservativt og nationalistisk publikum har vist sig uhyre effektiv for regeringen og gjort det muligt for den at sætte valgrekorder på stribe.

\section{Den tyrkiske stat talt midt imod}

Ingen bør bilde sig selv ind, at begivenhederne omkring Taksim-pladsen - omend betydningsfulde og historisk enestående - får væsentlig betydning på kort sigt for det politiske landskab i Tyrkiet. Lokalvalgene i marts 2014 samt parlamentsvalget året efter vil efter alt at dømme bekræfte dette.

Men det betyder bestemt ikke, at urolighederne er uvæsentlige. Tværtimod. For første gang i republikkens historie har middelklassen talt den hellige tyrkiske stat midt imod og vist sig villig til at risikere liv og lemmer på gaden. Såkaldt almindelige tyrkere fra storbyernes pæne gader har på håndfast vis brudt dogmet 
om, at statens vilje og rigide sikkerhedsdoktriner aldrig må udfordres af borgerne.

I Tyrkiet har statens tarv altid stået højere end borgerens. Et klippefast mantra, der har tjent statens traditionelle, militære magthavere godt.

Det er imidlertid ikke, fordi centralmagten i Ankara er fremmed for folkelige revolter. Landets kurdere har gjort væbnet oprør mod den kemalistiske sikkerhedsstat sammenlagt 29 gange i republikkens historie. Første gang i 1925 havde republikken blot to år på bagen.

Som følge er kurderne gennem årene blevet udråbt som landsforrædere og fjender af staten. Den systematiske skræmmekampagne havde et klart politisk sigte og mødte stor genklang i den øvrige befolkning, som bifaldt eller tav under adskillige massakrer på landets illoyale kurdere siden 1920'erne.

Det derimod nye og hidtil usete, der i juni 2013 udfoldede sig i Istanbul, er snarere, at den føjelige tyrkiske befolkning kastede frygten og apatien af sig og selvstændigt tog stilling til den kurs, staten og denne gang de islamiskkonservative magthavere tegner på samfundets vegne. Genopførelsen af det historiske militæranlæg på Taksim Pladsen, som i slutningen af maj udløste protesterne i Gezi Parken, blev blot den berømte sidste dråbe, der fik slipseklædte nationaltkonservative tyrkere til at slå pjalterne sammen med unge socialister, kurdere og andre oppositionelle kræfter mod en enevældig regeringschef.

\section{Erdogans magt}

I praksis bliver Tyrkiet i dag regeret ved diktat fra en enkelt mand, regeringschef og AKP-formand Recep Tayyip Erdogan. Hans næsten uindskrænkede politiske råderum overgår endda forsvarschefens ditto under militærets velmagtsdage.

Det er således i dag umuligt at iværksætte og gennemføre større eller mindre tiltag i samfundet uden et grønt lys fra Erdogan. Ligeledes kan Erdogan sætte en stopper for ethvert initiativ på regionalt $\mathrm{og}$ lokalt plan uden at blive afkrævet saglig argumentation. En indflydelse, han bruger nidkært i store som små spørgsmål. Erdogans personlige engagement i det omstridte byggeri på Taksim Pladsen i Istanbul, som formelt set falder ind under bystyret, er bare et eksempel. Et andet eksempel fra en nær fortid er hans krav om nedrivningen af et 25 meter højt fredsmonument ved grænsen til Armenien i 2011.

Under et besøg i byen Kars betegnede Erdogan monumentet som 'monstrøst' og forlangte, at bystyret fjernede det øjeblikkeligt. I sådan en situation er det politisk selvmord for en borgmester at sidde kravet fra Erdogan overhørig. Det er partiformand Erdogan, der fra hovedstaden personligt agerer lokal valgkreds og sammensætter kandidatlister til val- 
gene. Derfor er de folkevalgte politikere mere lydhøre over for partiformanden end over for deres vælgere.

Men Tyrkiet er under hastigt forandring. Det er for tidligt at spå om, hvilken betydning Gezi-optøjerne får for regeringen på sigt. Det er dog sikkert, at de dramatiske begivenheder udgør en stor og vægtig milepæl i AKP's levetid og derfor potentielt set for Tyrkiets politiske fremtid.

\section{Historisk tungtvejende dagsorden}

Da kampene mellem demonstranter og politi erobrede den nationale og for en stund også den internationale dagsorden, skete det på bekostning af en anden og for Tyrkiet langt mere presserende og historisk vægtig dagsorden: de politiske forhandlinger med den kurdiske oprørsbevægelse, Kurdistans Arbejderparti, PKK.

Der har gennem en årrække været pres på regeringen for at genoptage dialogen med PKK-ledelsen. Da forhandlingerne kuldsejlede i 2009 som følge af pres fra AKP's højrefløj, fulgte en storstilet militæroffensiv mod PKK-styrker og en omfattende arrestationsbølge rettet mod tusinder af kurdiske borgmestre, græsrødder og andre civile aktivister i kurdisk politik.

Regeringen var dengang ikke parat til at bakke forhandlingerne op med demokratiske lovreformer såsom statsgaranteret modersmålsundervisning, øget lokalstyre og sænkning af spærregrænsen på ti pro- cent. Det var således mere opportunt for regeringen at trække stikket til forhandlingerne og skrue op for den nationalistiske retorik for at tækkes høgene. Både internt i partiet og statsapparatet og blandt vælgerne.

Partiets politiske projekt står langt mere sikkert på skuldrene af islamonationalistiske vælgere, end det gør hos liberale midtervælgere og kurdere, lød kalkulen. To år efter slog AKP igen en valgrekord og fik 49,9 procent af stemmerne ved det seneste parlamentsvalg. Den politiske risiko ved fredsprocessen vejede tungere end udsigten til måske at blive den første regering med en fornuftig løsning af kurderproblematikken.

\section{Svendeprøven}

Det kurdiske spørgsmål er Tyrkiets mest betændte politiske problem, og sådan har det været siden den tyrkiske republik blev skabt. Politikere har gennem tiderne både risikeret deres politiske karrierer samt liv og lemmer i bogstaveligste forstand i forsøget på at løse den gordiske knude. Det er den ultimative svendeprøve i tyrkisk politik. Kurderne tabte efter Første Verdenskrig det politiske slag om at opnå den samme selvbestemmelse, som araberne delvist havde opnået ved Osmannerrigets sammenbrud og opsplitning $\mathrm{i}$ en række nye stater.

Kurderne havde nydt en udstrakt grad af selvstyre under den tyrkiske 
sultan. Han var nødsaget til at alliere sig med de magtfulde kurdiske klaner for at få ro på bagsmækken, mens krigene rasede rundt om i imperiet. Men den revolutionære nationalist, general Mustafa Kemal, overtalte under krigen kurderne til at skifte side til fordel for de sekulære kemalister mod et løfte om at fortsætte det kurdiske selvstyre under en kommende republik.

Med kurdernes støtte formåede Kemal ikke alene at vælte sultanen, men at kontrollere et langt mere vidstrakt territorium, end tyrkerne oprindeligt stod til at beholde under aftalen med de britiske og franske kolonimagter.

\section{Uindfriet løfte}

Tyrkiet var skabt. Men løftet til kurderne blev som bekendt aldrig indfriet. Regionens nye grænsedragninger skar igennem det kurdiske selvstyreområde. Den kurdiske befolkning var nu delt mellem Tyrkiet og to andre af Mellemøstens nye stater, Syrien og Irak, samt Iran.

Det dybe politiske problem, vi i dag kalder det kurdiske spørgsmål, udspringer således af et territoriekrav og er derfor mere end bare et spørgsmål om borgerrettigheder og kulturelle rettigheder som sprog og undervisning.

Området, som myndighederne i årtier har kaldt Øst- og Sydøsttyrkiet, bliver af kurderne selv kaldt Nordkurdistan og er etnisk set et re- lativt homogent område bestående af 15-20 millioner kurdere. Atter millioner af kurdere har gennem årene søgt til tyrkiske storbyer som for eksempel Istanbul, som USA's udenrigsministerium i en rapport i 2010 betegnede som 'verdens største kurdiske metropol'.

Kurdisk er fortsat en naturlig del af dagligdagen i landets kurdiske region, selv om myndighederne officielt ikke tillader brugen af sproget $\mathrm{i}$ for eksempel valgkampe, i borgerens kontakt med kommunekontorer og myndighedspersoner og lignende.

Området har altid været uroligt, fordi republikkens generaler altid har set på kurderne med mistro og holdt civilbefolkningen i kort snor. En jernnæve, der kun blev mere uforsonlig efter militærkuppet i 1980, hvorefter kurdisk som sprog blev kriminaliseret.

Juntalederen general Kenan Evren er berømt for offentligt at omtale kurderne som en art primitive bjergtyrkere. Den hårde kurs medførte en gennemmilitarisering af civile beboelsesområder, tvangsrømning og nedbrænding af op mod 4.000 kurdiske landsbyer og skabte millioner af internt fordrevne og dertil en hel generation af dissidenter.

Det kurdiske oprør, der skulle komme i kølvandet på 1980-kuppet, har vist sig at være det hidtil mest sejllivede af slagsen. PKK erklærede den tyrkiske stat krig i 1984. Men al- 
lerede ved udgangen af den kolde krig var bevægelsen vokset mangefoldig både som organisation og militær slagstyrke og udgjorde et alvorligt sikkerhedsproblem for det tyrkiske statsapparat.

I folkemunde siges det, at Kurdistans Arbejderparti, PKK, blev skabt i militærfængslerne, hvor kurdere i tusindvis blev tortureret eller ligefrem dræbt uden rettergang.

\section{Største samfundsmæssige problem}

Den udbredte fortælling om PKK som en slags modtryk til militærets undertrykkelse af den kurdiske befolkning afspejler i dag dybden af Tyrkiets såkaldte kurdiske spørgsmål. Republikkens nuværende præsident og AKP-medstifter, Abdullah Gül, har ved flere lejligheder betegnet det kurdiske spørgsmål som 'landets største samfundsmæssige problem'.

Det er med til at understrege, at der ikke er tale om et sikkerhedsproblem, der kun kan løses ved militære midler, men i høj grad et åbent samfundsmæssigt sår, der skal forklares af sociologer og historikere og løses af reformpolitikere. Kurderne anslås at udgøre 20-25 millioner ud af Tyrkiets officielle 72 millioner indbyggere.

Mens samtlige af republikkens hidtidige regeringer dels har manglet reformambitionen og dels været bundet på hænder og fødder af generalerne, har AKP som den første regering $\mathrm{i}$ tyrkisk historie været $\mathrm{i}$ stand til at tøjle militæret og i et vist omfang vist sig villig til at løfte kurderne ud af sikkerhedsparadigmet. Det skyldes først og fremmest, at AKP som den første regering har opdaget det vælgermæssige potentiale $i$ at blive betragtet som kurdervenlig og reformivrig.

Regeringen er også gang på gang blevet belønnet af vælgerne for det samme, selv om den endnu ikke kan fremvise nævneværdige, demokratiske lovreformer til trods for lejlighedsvise hensigtserklæringer. Men tiderne er skiftet i Tyrkiet. Kravet om en øget inklusion af kurderne i det politiske liv på linje med tyrkerne deles nu af flere og flere vælgere blandt også tyrkerne. Dette er en stærk drivkraft bag regeringens andet forsøg på et politisk forlig med PKK.

Men til forskel fra 2009 er der denne gang en langt mere akut udenrigspolitisk dimension til det kurdiske spørgsmål.

Selv om Gezi-protesterne fik AKP til at hæve paraderne i forsvarsposition, suspendere al snak om demokratiske reformer og skrue op for populistiske sikkerhedssparoler, så har realiteterne syd for grænsen tvunget regeringen til at genoptage fredsprocessen omend modvilligt.

\section{Et nyt udenrigspolitisk regnestykke}

De arabiske revolter, der har præget Mellemøsten og Nordafrika de sene- 
ste år, har vendt op og ned på Tyrkiets udenrigspolitiske regnestykker, og regeringen endnu ikke har formuleret en udenrigspolitik, der kan holde Tyrkiet fri for konflikter snarere end tiltrække dem. AKP's linje udadtil er nemlig i stigende grad synonymt med sunni-fraternisme og pludselige værdikorstog dikteret af Erdogans idiosynkrasier. Altså langt fra velovervejet og levedygtig realpolitik.

Det har så godt som udslettet Tyrkiets unikke soft power-instrument i regionen. Især borgerkrigen i Syrien har vist sig at blive et vendepunkt for Tyrkiet, der er gået fra at kultivere stærke bånd til Assad-familien til at advokere for et regimeskifte med magt.

Styret i Damaskus har ikke siddet kursskiftet overhørigt. Man var udmærket klar over, hvilken hovedpine det ville udløse for tyrkerne, da de syriske sikkerhedstyrker sidste år trak sig ud af de nordøstligste, kurdiske områder langs grænsen til Tyrkiet. Resultatet var et kortvarigt magttomrum, der som ventet lynhurtigt blev udfyldt af kurdiske militser fra det lokale Demokratisk Enhedsparti, PYD, som er PKK's syriske søsterparti.

Partiet er det største og mest velorganiserede blandt kurderne i Syrien. Bevægelsen gjorde fælles front med det næststørste PDKS, der er tro mod det irakiskkurdiske regeringsparti, KDP. Sammen udgør de det Kurdiske Nationalråd, KNC.
Men i praksis er det altså PKK gennem PYD, som dominerer dagsordenen og kontrollerer den fælles milits kaldet Folkets Forsvarsbrigader, YPG.

Siden deres magtovertagelse har de syriske kurdere langsomt men sikkert udbygget deres områder med selvforvaltende byråd sammensat af lokale, skoler og et stående sikkerhedsapparat. PYD har således lagt kimen til et fremtidigt selvstyre inden for grænserne af en arabisk republik i lighed med situationen $\mathrm{i}$ Irak. Målet er at danne urokkelige realiteter på landjorden, der gør kurderne til uomgængelige forhandlingspartnere ved fredskonferencen kaldet Genève 2 og den dag, hvor det nye Syrien skal forhandles på plads.

\section{Ikke ene om at svinge taktstokken}

Men udsigten til et autonomt PKKland klods op ad Tyrkiets grænser er nok til at bringe hele det tyrkiske sikkerhedsapparat i højeste alarmberedskab.

Ankara har aldrig været i tvivl: Kurdere er farlige - og kurdere uden for den tyrkiske stats kontrol er livsfarlige. Først for ganske nyligt har Tyrkiet lært at leve med det kurdiske selvstyre i Irak, der tilmed er en af USA's nærmeste allierede i Mellemøsten. Men Tyrkiet er ikke længere ene om at svinge taktstokken $\mathrm{i}$ spørgsmålet om kurderne. Hverken nationalt eller internationalt.

Udviklingen i de kurdiske dele af 
Syrien har fået irreversibel betydning for tyrkiske indenrigsforhold. Med de syriske kurderes nye politiske projekt har den tyrkiske regering tabt initiativ $i$ håndteringen af sin egen kurdiske konflikt.

PKK har ikke længere nær så travlt med at indgå et forlig med tyrkerne. Gennem sit syriske søsterparti, PYD, har PKK for første gang i bevægelsens historie opnået relativ blød magt og kan øve politisk indflydelse på Tyrkiet uden brugen af direkte vold. Hertil kommer den økonomiske magt ved indtægtsmulighederne fra de store oliefelter i Rumeillah i Nordøstsyrien, som lige nu indirekte kontrolleres PKK.

\section{Fremtiden for de syriske kurdere}

Den politiske fremtid ser lovende ud for de syriske kurdere. I august fik de et vigtigt rygstød af den russiske udenrigsminister Sergei Lavrov, der krævede, at kurderne fik deres egen stol ved anden runde af fredsforhandlingerne i Geneve.

Udsigten, som mere end noget andet jager en skræk i livet på den tyrkiske regering er, at PKK kunne blive en del af en politisk samlingsregering i Damaskus eller en permanent bestanddel af en syrisk magtdeling efter sekteriske skillelinjer sådan som vi har set udført i Libanon og Irak.

Det scenarie er ikke lige rundt om hjørnet, men i Tyrkiet har man set skriften på væggen. Det vækker nem- lig ængstelse, at ingen af landets vestlige allierede synes at dele tyrkernes bekymring om PKK's nuværende såvel som fremtidige rolle $\mathrm{i}$ Syrien.

Både i vestlige hovedstæder og $\mathrm{i}$ Moskva er man yderst tilfreds med, at der i PYD findes en sekulær militærmagt i Syrien, der både er villig og i stand til at bekæmpe al Qaedaaffilierede grupper som Jabhat al Nusra og ISIS.

Man er ikke mindst tilfreds med en syrisk befolkningsgruppe, der i fremtidens politiske ligning kan agere modvægt over for det Muslimske Broderskab i Damaskus. Nøjagtig som de irakiske kurdere holder den shia-arabiske premierminister i Baghdad, Nuri al Maliki, i ørerne og således er med til delvist at begrænse iransk indflydelse.

Men som på så mange andre områder i Mellemøsten er Tyrkiets og Vestens interesser ikke sammenfaldende. Tyrkiet anser situationen som et minefelt. Hvis PKK kan gøre sig nyttig eller ligefrem uundværlig for Vesten som politisk allieret i Syrien, kan det i sidste ende resultere i et PKK-kontrolleret kurdisk selvstyre inden for tyrkiske grænser, frygter tyrkerne.

\section{Fortsat dialog}

Derfor er den tyrkiske regering pisket til at fortsætte dialogen for dels at indhente noget af det tabte initiativ og dels at forhindre, at PKK bru- 
ger den regionale udvikling mod

Tyrkiet.

Efteråret 2013 har kritisk betydning. PKK har startet en ensidig tilbagetrækning af sine guerillastyrker til lejrene i Nordirak. Den forventes afsluttet senest i oktober. Den klare forventning er, at den tyrkiske regering honorerer sin del af aftalen og lemper de udskældte restriktioner på valg, ytrings-, forenings- og undervisningsfrihed, som er en klods om benet på den kurdiske politiske bevægelse i både parlamentet og på gaden.

Men AKP har allerede begyndt sin valgkamp, der i varierende tempi kommer til at vare i to år. Frem mod lokalvalgene i marts 2014 samt præsidentvalget i november samme år, hvor premierminister Erdogan selv ventes at stille op, og endeligt parlamentsvalget i juni 2015.

Spørgsmål er nu, om Erdogan er villig til at risikere sit politiske projekt for en varig fred.

Pola Rojan Bagger er journalist ved TV2, forfatter og tidligere Tyrkiet-korrespondent for Morgenavisen JyllandsPosten. 